Marquette University

e-Publications@Marquette

1984

\title{
The Structure of 1-tert-butyl-2,2,3,4,4-pentamethylphosphetane 1-oxide, $\mathrm{C}_{12} \mathrm{H}_{25} \mathrm{OP}$
}

J. A. Campbell

Montana State University - Bozeman

C. N. Caughlan

Montana State University - Bozeman

A. Fitzgerald

Saint Martin's College

C. Campana

Nicolet Analytical Instruments

Sheldon E. Cremer

Marquette University, sheldon.cremer@marquette.edu

Follow this and additional works at: https://epublications.marquette.edu/chem_fac

Part of the Chemistry Commons

\section{Recommended Citation}

Campbell, J. A.; Caughlan, C. N.; Fitzgerald, A.; Campana, C.; and Cremer, Sheldon E., "The Structure of 1-tert-butyl-2,2,3,4,4-pentamethylphosphetane 1-oxide, $\mathrm{C}_{12} \mathrm{H}_{25} \mathrm{OP}$ " (1984). Chemistry Faculty Research and Publications. 908.

https://epublications.marquette.edu/chem_fac/908 


\title{
The Structure of 1-tert-Butyl-2,2,3,4,4-pentamethylphosphetane 1-Oxide, $\mathrm{C}_{12} \mathrm{H}_{25} \mathrm{OP}$
}

\author{
By J. A. Campbell* ${ }^{*}$ and C. N. Caughlan \\ Department of Chemistry, Montana State University, Bozeman, Montana 59717, USA \\ A. FitzGERALD \\ Department of Chemistry, Saint Martin's College, Lacey, Washington 98503, USA \\ C. Campana \\ Nicolet Analytical Instruments, Madison, Wisconsin 53711, USA \\ AND S. E. CREMER \\ Department of Chemistry, Marquette University, Milwaukee, Wisconsin 53233, USA
}

(Received 16 March 1984; accepted 6 July 1984)

Abstract. $\quad M_{r}=216 \cdot 30$, monoclinic, $P 2 / m, \quad a=$ 6.137 (2), $\quad b=12.181(4), \quad c=9.005$ (3) $\AA, \quad \beta=$ $96.24(3)^{\circ}, V=669 \cdot 2(9) \AA^{3}, Z=2, D_{m}=1.06, D_{x}$ $=1.07 \mathrm{~g} \mathrm{~cm}^{-3}$, Mo $K \alpha, \lambda=0.71069 \AA, \mu=1.73 \mathrm{~cm}^{-1}$, $F(000)=240, \quad T=295 \mathrm{~K}, \quad R=0.052, \quad R_{w}=0.051$, 1138 observed reflections. The single methyl group on $\mathrm{C}(3)$ is trans to the tert-butyl group on P. The four-membered ring is puckered with an angle of

* Address all correspondence to this author.

† Present address: Dow Chemical Company, Analytical Laboratory, 574 Building, Midland, MI 48640, USA.

0108-2701/84/111918-03\$01.50
$19 \cdot 2(4)^{\circ}$, and the direction of ring puckering is such that the diaxial cross-ring interactions $\left(\mathrm{CH}_{3}\right.$ and $\left.\mathrm{O}\right)$ between the substituents on $\mathrm{P}$ and $\mathrm{C}(3)$ are minimized.

Introduction. The structural analysis of 1-tert-butyl2,2,3,4,4-pentamethylphosphetane 1-oxide (TPPO) was undertaken to confirm the stereochemistry, the direction and amount of puckering in the fourmembered ring, and to compare the results with predictions based on previous results of similar compounds. The title compound was prepared by previously published methods (Gray \& Cremer, 1972).

c) 1984 International Union of Crystallography 


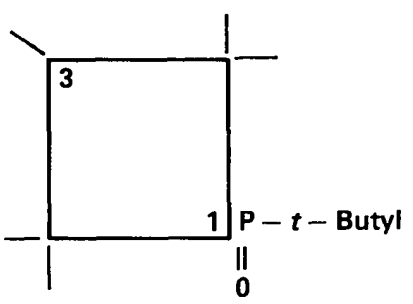

Experimental. $D_{m}$ by flotation in ethanol and methyl iodide mixture, colorless crystals of TPPO suitable for $\mathrm{X}$-ray analysis obtained by recrystallization from cyclohexane. Crystal size $0.4 \times 0.1 \times 0.2 \mathrm{~mm}$. Nicolet $R 3 m$ diffractometer, graphite monochromator (Campana, 1981), accurate unit-cell parameters from leastsquares refinement of 25 reflections $\left(\theta\right.$ range $\left.10-15^{\circ}\right)$, two standard reflections (040 and 200) measured every $120 \mathrm{~min}, 4 \%$ variation. Range of $h k l: 0 \leq h \leq 8$, $0 \leq k \leq 16,-12 \leq l \leq 12$. 1845 data measured $\left(3 \leq 2 \theta \leq 55^{\circ}\right), 1138$ with $I \geq 3 \sigma(I)$; corrections for Lorentz and polarization effects (absorption and time decay ignored). Trial structure by direct methods and refined by full-matrix least-squares procedures, function minimized $\sum w\left(\left|F_{o}\right|-\left|F_{c}\right|\right)^{2}$ where $w=1 /\left[\sigma^{2}(F)+\right.$ $\left.G(F)^{2}\right]$ and $G=0.001$; non-hydrogen atoms anisotropic, $\mathrm{H}$ atoms located in $\Delta F$ map and idealized coordinates calculated and not refined, isotropic thermal parameters for $\mathrm{H}$ assigned as $1.2 \times$ value for $\mathrm{C}$ to which they are attached, $R=0.052$ and $R_{w}=0.051$, scattering factors for $\mathrm{P}, \mathrm{O}, \mathrm{C}$ and $\mathrm{H}$ from International Tables for $X$-ray Crystallography (1962), $S=1 \cdot 27$. In final cycle $(\Delta / \sigma)_{\max }=0.006$; final difference map showed no peaks or depressions larger than $0.2 \mathrm{e} \AA^{-3}$. Calculations carried out with SHELXTL package on Nicolet $R 3 m$ crystallographic system (Sheldrick, 1980).*

Discussion. The atomic fractional coordinates with their standard deviations and $U_{\mathrm{eq}}$ values (Hamilton, 1959) are given in Table 1. The structure and numbering scheme of the title compound are shown in Fig. 1. Table 2 is a listing of selected interatomic distances and angles with their standard deviations.

The single methyl group on $\mathrm{C}(3)$ is trans to the tert-butyl group on phosphorus. The mirror plane passes through the $\mathrm{P}$ and $\mathrm{O}$ atoms as well as $\mathrm{C}$ atoms $1,2,3$ and 8.

All phosphetane ring structures studied to date exhibit puckering of the four-membered ring. The amount of puckering in the four-membered ring is the angle between the planes defined by $\mathrm{C}(4)-\mathrm{P}-\mathrm{C}\left(4^{\mathrm{i}}\right)$ and

\footnotetext{
* Lists of structure factors, anisotropic thermal parameters and $\mathrm{H}$-atom parameters have been deposited with the British Library Lending Division as Supplementary Publication No. SUP 39629 (10 pp.). Copies may be obtained through The Executive Secretary, International Union of Crystallography, 5 Abbey Square, Chester $\mathrm{CH} 12 \mathrm{HU}$, England.
}

$\mathrm{C}(4)-\mathrm{C}(3)-\mathrm{C}\left(4^{1}\right)$. The amount of puckering in TPPO is $19 \cdot 2^{\circ}$. Qualitatively, the amount of puckering has been related to the number of substituent interactions (Fitzgerald, Campbell, Smith, Caughlan \& Cremer, 1978). An interaction is considered to exist between substituents that are attached to adjacent ring atoms

Table 1. Final atomic coordinates for non-hydrogen atoms with e.s.d.'s in parentheses and equivalent isotropic thermal parameters $\left(\AA^{2} \times 10^{2}\right)$

\begin{tabular}{lclll} 
& $x$ & $y$ & \multicolumn{1}{c}{$z$} & $U_{\mathrm{eq}}^{*}$ \\
$\mathrm{P}$ & $0.14872(16)$ & 0.25000 & $1.15899(11)$ & $4.40(3)$ \\
$\mathrm{C}(1)$ & $0.2071(6)$ & 0.2500 & $0.9623(4)$ & $4.95(12)$ \\
$\mathrm{O}(1)$ & $-0.0920(4)$ & 0.2500 & $1.1621(3)$ & $7.28(12)$ \\
$\mathrm{C}(2)$ & $0.4480(8)$ & 0.2500 & $0.9371(6)$ & $6.82(19)$ \\
$\mathrm{C}(3)$ & $0.4541(6)$ & 0.2500 & $1.3442(4)$ & $4.92(12)$ \\
$\mathrm{C}(4)$ & $0.3087(4)$ & $0.1518(2)$ & $1.2834(3)$ & $5.26(9)$ \\
$\mathrm{C}(5)$ & $0.4391(6)$ & $0.0581(3)$ & $1.2235(4)$ & $7.79(13)$ \\
$\mathrm{C}(6)$ & $0.0942(6)$ & $0.1487(3)$ & $0.8908(4)$ & $8.11(14)$ \\
$\mathrm{C}(7)$ & $0.1589(6)$ & $0.1051(4)$ & $1.3931(4)$ & $8.85(15)$ \\
$\mathrm{C}(8)$ & $0.5367(11)$ & 0.2500 & $1.5090(6)$ & $8.37(24)$
\end{tabular}

* $U_{\mathrm{eq}}$ is defined as one third of the orthogonalized $U_{i j}$ tensor.

Table 2. Selected bond angles $\left(^{\circ}\right)$ and bond distances $(\AA)$ with e.s.d.'s in parentheses

$\begin{array}{lllr}\text { P-C(1) } & 1.845(4) & \mathrm{C}(4)-\mathrm{P}-\mathrm{C}\left(4^{\prime}\right) & 80.7(2) \\ \mathrm{P}-\mathrm{O}(1) & 1.480(3) & \mathrm{C}(4)-\mathrm{C}(3)-\mathrm{C}\left(4^{\prime}\right) & 100.5(3) \\ \mathrm{P}-\mathrm{C}(4) & 1.846(3) & \mathrm{C}(3)-\mathrm{C}(4)-\mathrm{P} & 87.8(2) \\ & & \mathrm{C}(1)-\mathrm{P}-\mathrm{O}(1) & 108.5(2) \\ \mathrm{C}(1)-\mathrm{C}(2) & 1.520(6) & \mathrm{C}(1)-\mathrm{P}-\mathrm{C}(4) & 115.9(1) \\ \mathrm{C}(1)-\mathrm{C}(6) & 1.523(4) & \mathrm{C}(4)-\mathrm{P}-\mathrm{O}(1) & 117.0(1) \\ & & \mathrm{C}(2)-\mathrm{C}(1)-\mathrm{C}(6) & 110.0(2) \\ \mathrm{C}(3)-\mathrm{C}(4) & 1.556(4) & \mathrm{C}(2)-\mathrm{C}(1)-\mathrm{P} & 115.9(3) \\ & & \mathrm{C}(6)-\mathrm{C}(1)-\mathrm{P} & 106.2(3) \\ \mathrm{C}(3)-\mathrm{C}(8) & 1.518(7) & \mathrm{P}-\mathrm{C}(4)-\mathrm{C}(5) & 108.4(2) \\ \mathrm{C}(4)-\mathrm{C}(5) & 1.531(5) & \mathrm{P}-\mathrm{C}(4)-\mathrm{C}(7) & 122.3(2) \\ \mathrm{C}(4)-\mathrm{C}(7) & 1.526(5) & \mathrm{C}(3)-\mathrm{C}(4)-\mathrm{C}(5) & 114.8(2) \\ & & \mathrm{C}(3)-\mathrm{C}(4)-\mathrm{C}(7) & 113.4(2) \\ & & \mathrm{C}(4)-\mathrm{C}(3)-\mathrm{C}(8) & 117.6(2) \\ & & \mathrm{C}(6)-\mathrm{C}(1)-\mathrm{C}\left(6^{\prime}\right) & 108.2(3) \\ & & \mathrm{C}(8)-\mathrm{C}(4)-\mathrm{C}(7) & 109.0(3)\end{array}$

Symmetry code: (i) $x, \frac{1}{2}-y, z$.

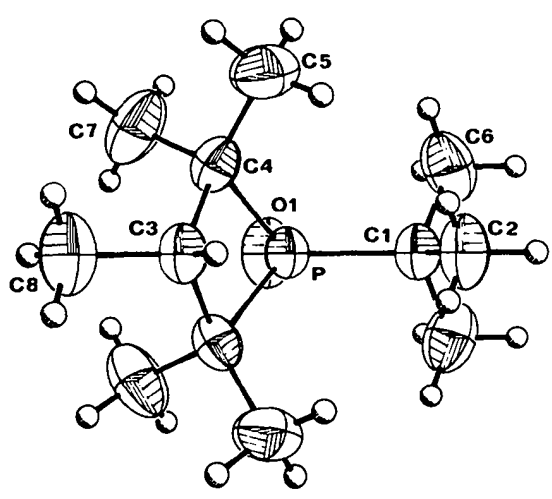

Fig. 1. The structure and numbering scheme for TPPO. Nonhydrogen atoms are represented as thermal ellipsoids scaled to enclose $50 \%$ probability. The hydrogen atoms are represented as spheres with $0.15 \AA$ radius in this illustration. 
and $c i s$ to one another with respect to the phosphetane ring system. The $\mathrm{C}(5)-\mathrm{C}(8)$ distance in TPPO is 3.010 (6) $\AA$, which is substantially less than a $3.4 \AA$ distance based on van der Waals radii (Bondi, 1964). The $\mathrm{C}(5)-\mathrm{O}(1)$ distance is 3.019 (5) $\AA$, which is also less than the sum of van der Waals radii (Bondi, 1964). Fitzgerald et al. (1978) found the amount of puckering to be in the range $19.6-24^{\circ}$ for similar compounds with two methyl-methyl interactions. The amount of puckering in TPPO is very close to this range and may, in fact, represent a lower limit for compounds with two cis methyl-methyl interactions.

With respect to puckering direction or conformation preferences for TPPO, the following conformers may be considered.

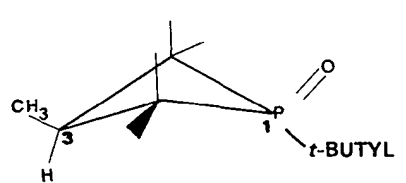

(1A)

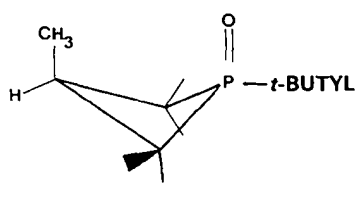

$(18)$
TPPO exists in form $(1 A)$, and the $\mathrm{C}(8)-\mathrm{O}$ distance of 4.69 (6) $\AA$ agrees well with similar compounds in which there is a single methyl group trans to a substituent on P (Fitzgerald et al., 1978) and with distances measured from the molecular model of $(1 A)$.

We thank G. D. Smith and K. Emerson for many helpful discussions and assistance.

\section{References}

Bondi, A. (1964). J. Phys. Chem. 68, 441-448.

Campana, C. F. (1981). Editor. Nicolet P3/R3 Data Collection Manual. Nicolet XRD Corp., Cupertino, CA.

Fitzgerald, A., Campbell, J. A., Smith, G. D., Caughlan, C. N. \& Cremer, S. E. (1978). J. Org. Chem. 43, 3513 3517.

Gray, G. A. \& Cremer, S. E. (1972). J. Org. Chem. 37, 3458-3469.

Hamilton, W. (1959). Acta Cryst. 12, 609-610.

International Tables for X-ray Crystallography' (1962). Vol. III, 2nd ed. Birmingham: Kynoch Press.

SHELDRICK, G. M. (1980). Editor. Nicolet SHELXTL Structure Determination Manual. Nicolet XRD Corp., Cupertino, CA. 